\title{
Lack of Prognostic Value of SARS-CoV2 RT-PCR Cycle Threshold in the Community
}

\author{
Miguel J. Martínez · Luca Basile • Antoni Sisó-Almirall • \\ Victor Cristino · Genoveva Cuesta · Juan Carlos Hurtado • \\ Mariana Fernandez-Pittol · María Mar Mosquera · Alex Soriano • \\ Ana Martínez $\cdot \mathrm{M}^{\mathrm{a}}$ Angeles Marcos $\cdot$ Jordi Vila $\cdot$ Climent Casals-Pascual
}

Received: September 29, 2021 / Accepted: October 26, 2021 / Published online: November 11, 2021

(C) The Author(s) 2021

\section{ABSTRACT}

The immense impact of the COVID-19 pandemic on health systems has motivated the scientific community to search for clinical prognostic factors for SARS-CoV-2 infection. Low cycle threshold values $(\mathrm{Ct})$ of diagnostic real-time RT-PCR assays in hospitalized patients have been associated with a poor prognosis in several studies, whereas other studies did not

M. J. Martínez · G. Cuesta · J. C. Hurtado .

M. Fernandez-Pittol · M. M. Mosquera .

M. A. Marcos · J. Vila · C. Casals-Pascual $(\bowtie)$

Department of Microbiology, CDB, Hospital Clinic, University of Barcelona, Barcelona, Spain

e-mail: ccasals@clinic.cat

M. J. Martínez · J. C. Hurtado - M. M. Mosquera .

M. A. Marcos · J. Vila · C. Casals-Pascual Barcelona Institute for Global Health (ISGlobal), Barcelona, Spain

L. Basile $\cdot$ V. Cristino $\cdot$ A. Martínez

Public Health Agency of Catalonia, Generalitat of

Catalonia, Barcelona, Spain

A. Sisó-Almirall

Consorci d'Atenció Primària de Salut Barcelona

Esquerra (CAPSBE), Barcelona, Spain

\section{A. Soriano}

Department of Infectious Diseases, Hospital Clinic of Barcelona-IDIBAPS, University of Barcelona,

Barcelona, Spain find this association. We explored whether SARS-CoV-2 Ct values at diagnosis were associated with a poor outcome (admission to hospital and death) in 604 community patients diagnosed at primary health centers. Although lower Ct values were found in patients who died of COVID-19, the Ct value was not significantly associated with a worse outcome in a multivariate analysis, while age remained an independent prognostic factor. We did not find evidence to support the role of Ct values as a prognostic factor of COVID-19 in community cases.

Keywords: SARS-CoV-2; Cycle threshold values; RT-PCR; Outcome; Community 


\section{Key Summary Points}

Why carry out this study?

SARS-CoV-2 viral load correlated with worse clinical outcome in hospitalized patients in some studies, but its routine use to guide clinical decisions is controversial

We explored whether SARS-CoV-2 realtime Low cycle threshold values $(\mathrm{Ct})$ values were associated with a poor prognosis in community patients diagnosed at primary health centers

\section{What was learned from the study?}

SARS-CoV-2 real-time Ct values were not associated with the severity of the disease in patients diagnosed at primary health centers

We did not find evidence to support the use of the Ct as a prognostic marker in patients diagnosed with COVID-19 in the community

\section{INTRODUCTION}

The utility of the real-time RT-PCR cycle threshold $(\mathrm{Ct})$ value or viral load in nasopharyngeal samples (NPS) as a predictor of SARS-CoV-2 severe disease remains unclear. On the one hand, several studies have reported an independent association of (1) Ct values at hospital admission with the risk of intubation [1] and mortality [1, 2], (2) Ct values at diagnosis with disease severity, survival and sequelae [3] and (3) viral load (RNA copies/ml) at the time of diagnosis with mortality [4]. On the other hand, other studies found no significant association among (1) viral load at hospital admission and length of oxygen support, admission to intensive care unit or overall survival [5], (2) initial Ct values and in-hospital mortality [6] or (3) viral load at the emergency department and admission to ICU or mortality [7]. Most of the above-mentioned studies assessing the clinical prognostic value of SARS-CoV-2 Ct values were performed in hospitalized patients. A recent systematic review and meta-analysis found no association between the $\mathrm{Ct}$ value and risk of hospitalization. However, among hospitalized patients, lower Ct was associated with increased disease severity and mortality [8]. Here, we explored the potential association of the SARSCoV-2 RT-PCR Ct value with the severity of the disease in the community by evaluating data of patients diagnosed at primary health care centers (PHCs).

\section{METHODS}

\section{Study Design}

All NPS for SARS-CoV-2 RT-PCR testing received from the PHCs in the catchment area of our hospital from June 2020 to January 2021 were included in the analysis. Duplicates were removed from the study, and only the first sample (or that closer to diagnosis) was evaluated. Epidemiological variables (age and sex), outcomes (hospital admission, intensive care admission and death) and the laboratory information of the patients were retrospectively retrieved from the medical and laboratory records of Hospital Clinic of Barcelona and data from the Public Health Agency of Catalonia, the public health authority responsible for the registration, notification and follow-up of SARSCoV-2 infections in our region. To reduce $\mathrm{Ct}$ data variability associated with diagnostic platforms, we present data using a single method for all tested cases: a self-adapted robotic platform (Opentrons OT) for nucleic acid extraction and RT-PCR set-up [9] using the TaqPath ${ }^{\mathrm{TM}}$ COVID-19 CE-IVD RT-PCR kit (ThermoFisher Scientific, Waltham, MA). This kit detects three SARS-CoV-2 target genes (N, Orf1ab and S) and an internal control. The study was approved by the hospital Ethics and Research Committee (File HCB/2021/0122).

\section{Databases and statistics}

The main dependent variable explored was death. However, due to the low mortality of 
community cases $(n=4)$, a composite outcome was defined (poor outcome) that included admission to hospital, admission to an intensive care unit (ICU) or death. The main independent variables studied were: age, sex and $\mathrm{Ct}$ values for the following genes: N, S and Orf1ab. The association of $\mathrm{Ct}$ with poor outcome or death was evaluated using a univariate (crude) and multivariate logistic regression adjusted for potential confounders. Statistical analysis was performed using Stata version 16.0 (StataCorp).

\section{RESULTS AND DISCUSSION}

All valid results obtained during the period of study (June 2020-January 2021) from samples submitted to our laboratory from five different PHCs were analyzed. The study flowchart is

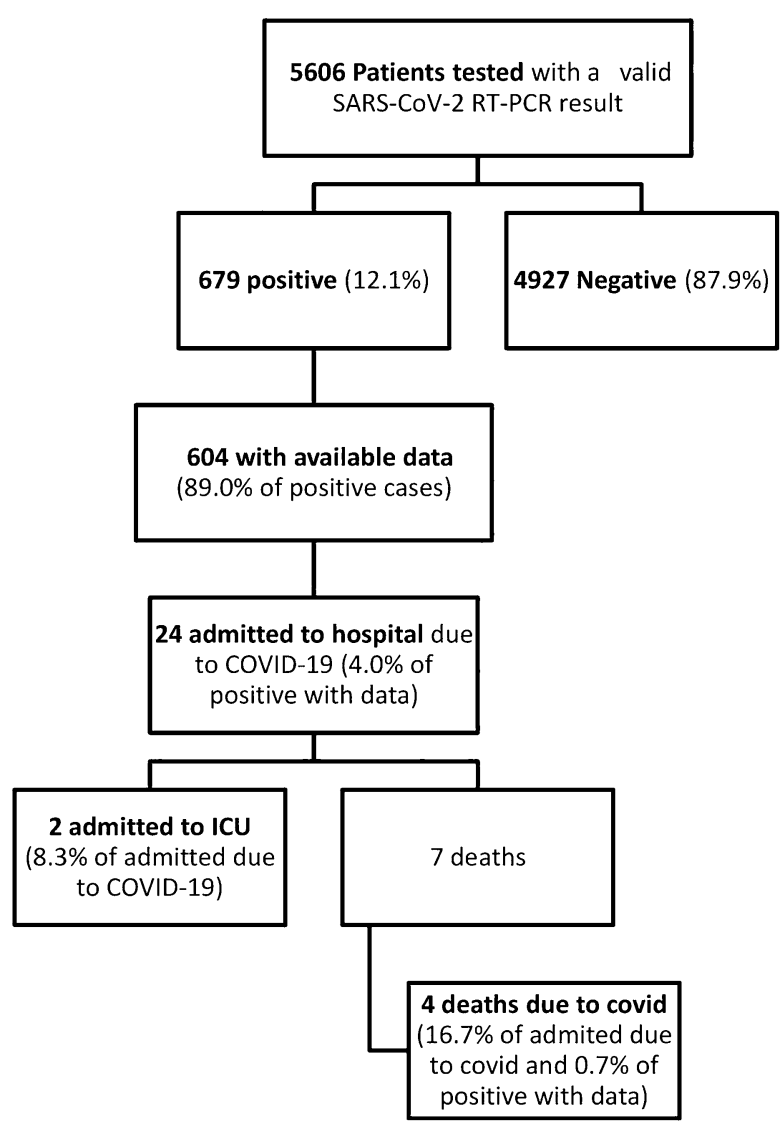

Fig. 1 SARS-CoV-2 RT-PCR results and clinical outcomes of patients screened at primary health centers shown in Fig. 1. More than 5500 patients were tested for SARS-CoV-2, and 679 resulted positive. Clinical and epidemiological data were available for 604 patients $(89.0 \%$ of positive cases). Twenty-four patients were admitted to the hospital, two of them were admitted to an ICU, and four patients died due to COVID-19.

The median (IQR) age of the population studied was 37 (25-54) years. Of 604 cases, 318 $(52.6 \%)$ were female. The median (IQR) $\mathrm{Ct}$ for
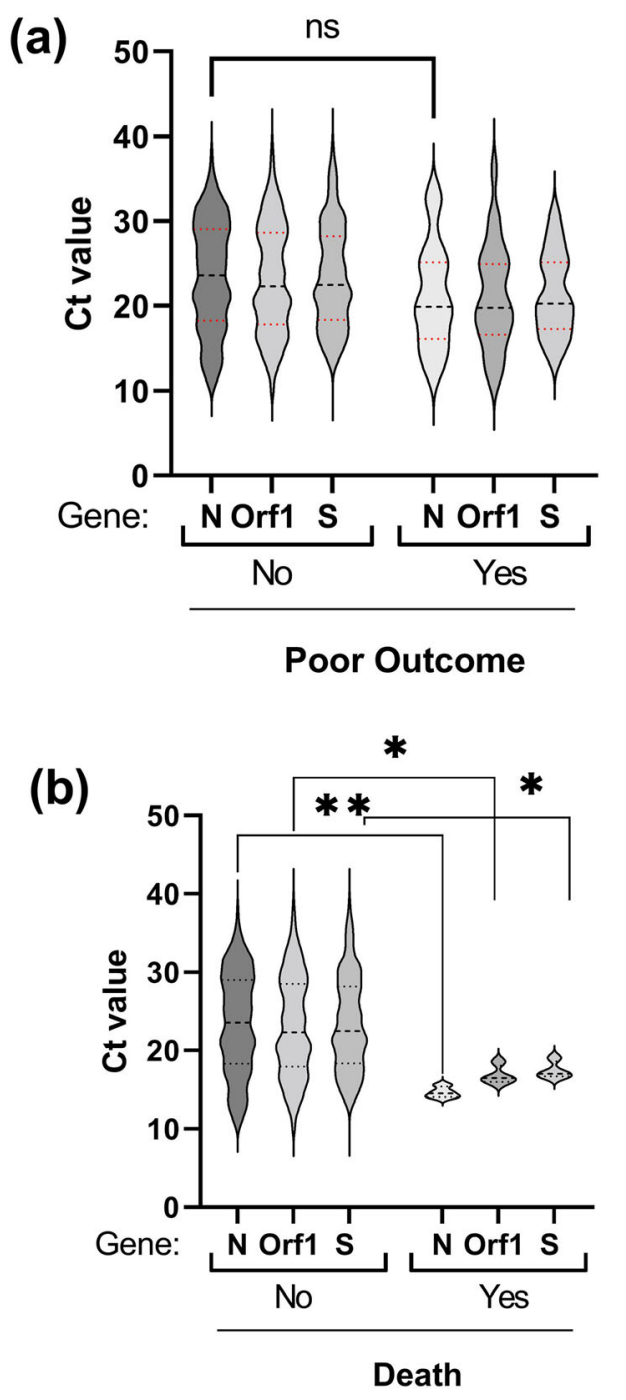

Fig. 2 SARS-CoV-2 cycle threshold $(\mathrm{Ct})$ value for the genes N, Orflab and S. a Poor clinical outcome (admission, admission to critical care and death) and $\mathbf{b}$ only fatal outcome. ${ }^{*} P<0.05,{ }^{* *} P<0.01$ 
the $\mathrm{N}$ gene was 23.5 (18.3-29.0) in the population studied and slightly lower [19.8 (16.1-25)] for those cases with a poor outcome (admission to hospital, ICU or death) although these differences were not statistically significant $(p=0.08)$ (Fig. 2a). When the analysis was repeated and $\mathrm{Ct}$ was compared between those who died $(n=4)$ and those who survived $(N=600)$, the median (IQR) differences were statistically significant (14.5 [14.1-15.2] vs. 23.5 [18.3-29], respectively; $p=0.007)$. This same pattern was observed for the $\mathrm{S}$ gene $(p=0.045)$ and for the ORF1 gene ( $p=0.045)$ (Fig. 2b).

To further ascertain the prognostic role of the cycle threshold, we performed a logistic regression model. In the initial univariate model, the patient's age (OR: 1.06, 95\% CI $1.04-1.08, p<0.001)$ and male gender $(2.8$ [1.14-6.87, $p=0.02]$ ) were associated with the composite poor outcome. In the multivariate model, age (OR: 1.07, 95\% CI 1.04-1.09, $p<0.001$ ) and male gender (OR: $5.48,95 \% \mathrm{CI}$ $1.99-15.1, p=0.001)$ remained associated with a poor outcome. The following variables were associated with death in the univariate analysis: the cycle threshold for the $\mathrm{N}$ gene (OR: 0.73, 95\% CI 0.55-0.96, $p=0.02$ ) and the patient's age (OR: 1.13, 95\% CI 1.03-1.25, $p=0.008$ ). Only age remained as an independent prognostic factor for death (OR: 1.13, 95\% CI $1.02-1.26, p=0.018$ ) whereas the Ct value was no longer significantly associated with a fatal outcome (OR: 0.67, 95\% CI 0.42-1.06, $p=0.08$ ) (Table 1).

In agreement with other studies, we observed a significant association of age and sex with poor COVID-19 outcome [3, 10]. Our results do not support the concept that the $\mathrm{Ct}$ value per se is a significant predictor of SARSCoV-2 infection outcome among outpatients. SARS-CoV-2 viral load is higher in the first days of symptoms [11] and seems not to differ by age in people $>20$ years $[12,13]$. Interestingly, SARS-CoV-2 viral loads in asymptomatic infections have been reported to be as high as in symptomatic patients [14, 15]. A wide range of real-time RT-PCR diagnostic assays that provide $\mathrm{Ct}$ values is available for SARS-CoV-2. However, significant variations in the $\mathrm{Ct}$ can be observed depending on the viral target gene amplified, amplification platform, RNA extraction method or quality of the clinical sample $[16,17]$. Several authors have highlighted these limitations suggesting that SARS-CoV-2 Ct values may not be recommended to guide clinical decisions as a general approach and rather should be interpreted with caution [18-20]. As NPS are not homogeneous in their cellular content and

Table 1 Uni- and multivariate analysis of association of cycle threshold, age and sex in relation to poor outcome and death

\begin{tabular}{|c|c|c|c|c|}
\hline \multirow[t]{2}{*}{ Variables } & \multicolumn{2}{|l|}{ Crude } & \multicolumn{2}{|l|}{ Adjusted } \\
\hline & $\overline{\mathrm{OR}}(95 \% \mathrm{CI})$ & $p$ value & OR (95\% CI) & $p$ value \\
\hline \multicolumn{5}{|c|}{ Poor outcome (admission/ICU/death) } \\
\hline $\mathrm{N}$ gene cycle threshold & $0.94(0.88-1.00)$ & 0.09 & $0.97(0.94-1.04)$ & 0.4 \\
\hline Age (years) & $1.06(1.04-1.08)$ & $<0.001$ & $1.07(1.04-1.09)$ & $<0.001$ \\
\hline Sex (male) & $2.8(1.14-6.87)$ & 0.024 & $5.48(1.99-15.1)$ & 0.001 \\
\hline \multicolumn{5}{|l|}{ Death } \\
\hline $\mathrm{N}$ gene cycle threshold & $0.73(0.55-0.96)$ & 0.027 & $0.67(0.42-1.06)$ & 0.088 \\
\hline Age (years) & $1.13(1.03-1.25)$ & 0.008 & $1.13(1.02-1.26)$ & 0.018 \\
\hline Sex (male) & $0.36(0.038-3.56)$ & 0.388 & na & na \\
\hline
\end{tabular}

Statistically significant values in bold

$\mathrm{Na}$ not applicable, as the variable was not selected in the univariate analysis 
depend on the collection of the sample, normalization of the viral gene $\mathrm{Ct}$ value with a cellular target has been proposed as a method to control evaluation errors that may occur using raw Ct data [21, 22]. Heterogeneity in the patients' clinical features, laboratory methods used and the clinical and laboratory variables analyzed among the different studies may explain the fact that the association of SARSCoV-2 viral load and disease outcome is not consistent in the literature. Standardization of the laboratory methodology (including normalization by cellular control genes) together with the inclusion of the main variables currently known to influence the course of the disease may result in a better understanding of the impact of viral load on COVID-19 infected patients.

This study has several limitations. First, the number of patients with a fatal outcome was low $(N=4)$, affecting the robustness of the initial multivariate model using death as dependent variable, and therefore studies including a larger number of deaths from patients diagnosed at the community would be desirable. However, the study was adequately powered to find differences in the rates of poor outcome as defined by admission to hospital or to a critical care unit or death in relation to the Ct. Second, the number of variables available for these patients was limited, and some important risk factors and comorbidities could have affected the study of these associations. Finally, the use of a single diagnostic platform, while it provides consistent and comparable values across all patients studied, may not translate well to other platforms, and further studies using different platforms should confirm these findings. In conclusion, as previously shown, age is a strong predictor of mortality and poor outcome. We could not find evidence to support the use of the $\mathrm{Ct}$ as a prognostic marker in patients diagnosed with COVID-19 in the community. Nonetheless, the $\mathrm{Ct}$ value seems relevant in terms of infection control for the identification of cases with high SARS-CoV-2 viral loads. The $\mathrm{Ct} /$ viral load values have been shown to correlate with the probability of viral isolation in cell culture and disease transmissibility. In fact, several studies have reported that a small proportion of cases with very high viral loads might be responsible for a significant number of secondary cases $[12,23,24]$.

\section{ACKNOWLEDGEMENTS}

We thank the participants of the study.

Funding. The study was partially supported by Agència de Gestió d'Ajuts Universitaris i de Recerca (AGAUR)-Departament d'Empresa i Coneixement. Generalitat de Catalunya (Grant 2017 SGR 794).

Authorship. All named authors meet the International Committee of Medical Journal Editors (ICMJE) criteria for authorship for this article, take responsibility for the integrity of the work as a whole, and have given their approval for this version to be published.

Author Contributions. Concept and design: Miguel J. Martínez, Luca Basile, Ana Martínez and Climent Casals-Pascual; clinical and laboratory data: Miguel J. Martínez, Luca Basile, Antoni Sisó-Almirall, Victor Cristino, Genoveva Cuesta, Juan Carlos Hurtado, Mariana Fernandez-Pittol, María Mar Mosquera, Alex Soriano; statistical analysis: Climent Casals-Pascual, drafting the manuscript: Ana Martínez, Miguel J. Martínez, $M^{\mathrm{a}}$ Angeles Marcos, Jordi Vila, Climent Casals-Pascual.

Disclosures. Miguel J. Martínez, Luca Basile, Antoni Sisó-Almirall, Victor Cristino, Genoveva Cuesta, Juan Carlos Hurtado, Mariana Fernandez-Pittol, María Mar Mosquera, Alex Soriano, Ana Martínez, $\mathrm{M}^{\mathrm{a}}$ Angeles Marcos, Jordi Vila and Climent Casals-Pascual all have nothing to disclose.

Compliance with Ethics Guidelines. This study was approved by the Ethics and Research Committee of Hospital Clinic de Barcelona (File HCB/2021/0122).

Data Availability. The datasets generated during and/or analyzed during the current 
study are available from the corresponding author on reasonable request.

Open Access. This article is licensed under a Creative Commons Attribution-NonCommercial 4.0 International License, which permits any non-commercial use, sharing, adaptation, distribution and reproduction in any medium or format, as long as you give appropriate credit to the original author(s) and the source, provide a link to the Creative Commons licence, and indicate if changes were made. The images or other third party material in this article are included in the article's Creative Commons licence, unless indicated otherwise in a credit line to the material. If material is not included in the article's Creative Commons licence and your intended use is not permitted by statutory regulation or exceeds the permitted use, you will need to obtain permission directly from the copyright holder. To view a copy of this licence, visit http://creativecommons.org/licenses/by$\mathrm{nc} / 4.0 /$.

\section{REFERENCES}

1. Magleby R, Westblade LF, Trzebucki A, Simon MS, Rajan M, Park J, et al. Impact of severe acute respiratory syndrome coronavirus 2 viral load on risk of intubation and mortality among hospitalized patients with coronavirus disease 2019. Clin Infect Dis. 2020. https://doi.org/10.1093/cid/ciaa851/ 5865363 (cited 3 May 2021).

2. Westblade LF, Brar G, Pinheiro LC, Paidoussis D, Rajan M, Martin P, et al. SARS-CoV-2 viral load predicts mortality in patients with and without cancer who are hospitalized with COVID-19. Cancer Cell. 2020;38(5):661-671.e2. https://doi.org/10. 1016/j.ccell.2020.09.007.

3. Trunfio M, Venuti F, Alladio F, Longo BM, Burdino E, Cerutti F, et al. Diagnostic SARS-CoV-2 cycle threshold value predicts disease severity, survival, and six-month sequelae in COVID-19 symptomatic patients. Viruses. 2021;13(2). https://pubmed.ncbi. nlm.nih.gov/33670360/. Accessed 2 May 2021.

4. Pujadas E, Chaudhry F, McBride R, Richter F, Zhao $\mathrm{S}$, Wajnberg A, et al. SARS-CoV-2 viral load predicts COVID-19 mortality. Lancet Respir Med. 2020;8(9): e70. https://doi.org/10.1016/S2213-2600(20)303544.
5. Argyropoulos KV, Serrano A, Hu J, Black M, Feng X, Shen $G$, et al. Association of initial viral load in severe acute respiratory syndrome coronavirus 2 (SARS-CoV-2) patients with outcome and symptoms. Am J Pathol. 2020;190(9):1881-7. https://doi. org/10.1016/j.ajpath.2020.07.001.

6. Carrasquer A, Peiró ÓM, Sanchez-Gimenez R, LalTrehan N, del-Moral-Ronda V, Bonet G, et al. Lack of association of initial viral load in SARS-CoV-2 patients with in-hospital mortality. Am J Trop Med Hyg. 2021;104(2):540-5.

7. Le Borgne P, Solis M, Severac F, Merdji H, Ruch Y, Alamé Intern $\mathrm{K}$, et al. SARS-CoV-2 viral load in nasopharyngeal swabs in the emergency department does not predict COVID-19 severity and mortality. Acad Emerg Med. 2021;28(3):306-13.

8. Shah VP, Farah WH, Hill JC, Hassett LC, Binnicker MJ, Yao JD, et al. Association between SARS-CoV-2 cycle threshold values and clinical outcomes in patients with COVID-19: a systematic review and meta-analysis. Open Forum Infect Dis. 2021. https://doi.org/10.1093/ofid/ofab453/6360381 (cited 14 Sep 2021).

9. Villanueva-Cañas JL, Gonzalez-Roca E, Unanue AG, Titos E, Yoldi MJM, Gómez AV, et al. Implementation of an open-source robotic platform for SARSCoV-2 testing by real-time RT-PCR. PLoS One. 2021;16(7):1-11.

10. Peckham H, de Gruijter NM, Raine C, Radziszewska A, Ciurtin C, Wedderburn LR, et al. Male sex identified by global COVID-19 meta-analysis as a risk factor for death and ITU admission. Nat Commun. 2020;11(1):1-10. https://doi.org/10.1038/s41467020-19741-6.

11. Cevik M, Tate M, Lloyd O, Maraolo AE, Schafers J, Ho A. SARS-CoV-2, SARS-CoV, and MERS-CoV viral load dynamics, duration of viral shedding, and infectiousness: a systematic review and meta-analysis. Lancet Microbe. 2021;2(1):e13-22. https://doi. org/10.1016/S2666-5247(20)30172-5.

12. Jones TC, Biele G, Mühlemann B, Veith T, Schneider J, Beheim-Schwarzbach J, et al. Estimating infectiousness throughout SARS-CoV-2 infection course. Science. 2021;373(6551). https://doi.org/10. 1126/science.abi5273.

13. Mahallawi WH, Alsamiri AD, Dabbour AF, Alsaeedi $\mathrm{H}$, Al-Zalabani AH. Association of viral load in SARS-CoV-2 patients with age and gender. Front Med. 2021;8:1-5.

14. Zou L, Ruan F, Huang M, Liang L, Huang H, Hong Z, et al. SARS-CoV-2 viral load in upper respiratory specimens of infected patients. $\mathrm{N}$ Engl J Med. 
2020;382(12):1177-1179. https://pubmed.ncbi. nlm.nih.gov/32074444/. Accessed 5 May 2021.

15. Singanayagam A, Patel M, Charlett A, Bernal JL, Saliba V, Ellis J, et al. Duration of infectiousness and correlation with RT-PCR cycle threshold values in cases of COVID-19, England, January to May 2020. Eurosurveillance. 2020;25(32):1-5.

16. Buchta C, Görzer I, Chiba P, Camp JV, Holzmann H, Puchhammer-Stöckl E, et al. Variability of cycle threshold values in an external quality assessment scheme for detection of the SARS-CoV-2 virus genome by RT-PCR. Clin Chem Lab Med. 2021;59(5). https://pubmed.ncbi.nlm.nih.gov/33554519/. Accessed 5 May 2021.

17. Matheeussen V, Corman VM, Mantke OD, McCulloch E, Lammens C, Goossens $\mathrm{H}$, et al. International external quality assessment for SARSCoV-2 molecular detection and survey on clinical laboratory preparedness during the COVID-19 pandemic. Eurosurveillance. 2020;25(27):6-10.

18. Rhoads D, Peaper DR, She RC, Nolte FS, Wojewoda $\mathrm{CM}$, Anderson NW, et al. College of American Pathologists (CAP) Microbiology Committee perspective: caution must be used in interpreting the cycle threshold (Ct) value. Clin Infect Dis. 2021 May 18;72(10):e685-6. https://doi.org/10.1093/cid/ ciaa1199.

19. Bustin S, Mueller R, Shipley G, Nolan T. Covid-19 and diagnostic testing for SARS-CoV-2 by RTqPCR_facts and fallacies. Int J Mol Sci. 2021;22(5): $1-11$.

20. Buchta C, Görzer I, Chiba P, Camp JV, Holzmann $\mathrm{H}$, Puchhammer-Stöckl E, et al. Variability of cycle threshold values in an external quality assessment scheme for detection of the SARS-CoV-2 virus genome by RT-PCR. Clin Chem Lab Med. 2021;59(5): 987-94.

21. Miranda RL, Guterres A, de Azeredo Lima CH, Filho PN, Gadelha MR. Misinterpretation of viral load in COVID-19 clinical outcomes. Virus Res. 2021;296. https://pubmed.ncbi.nlm.nih.gov/33592214/. Accessed 5 May 2021.

22. Dahdouh E, Lázaro-Perona F, Romero-Gómez MP, Mingorance J, García-Rodriguez J. Ct values from SARS-CoV-2 diagnostic PCR assays should not be used as direct estimates of viral load. J Infect. 2021;82:414-451. https://www.ncbi.nlm.nih.gov/ pmc/articles/PMC7585367/. Accessed 5 May 2021.

23. Marks M, Millat-Martinez P, Ouchi D, Roberts CH, Alemany A, Corbacho-Monné $\mathrm{M}$, et al. Transmission of COVID-19 in 282 clusters in Catalonia, Spain: a cohort study. Lancet Infect Dis. 2021;21(5): 629-36.

24. Yang Q, Saldi TK, Gonzales PK, Lasda E, Decker CJ, Tat KL, et al. Just $2 \%$ of SARS-CoV-2-positive individuals carry $90 \%$ of the virus circulating in communities. 2021;1-6. Proc Natl Acad Sci U S A. 2021;118(21):e2104547118. https://doi.org/10. 1073/pnas.2104547118.

\section{Publisher's Note}

Springer Nature remains neutral with regard to jurisdictional claims in published maps and institutional affiliations 